\title{
IMPLEMENTATION OF ZAKAT ACCOUNTING BASED ON PSAK 109 IN LAZISMU PAYAKUMBUH CITY \\ Widi Nopiardo ${ }^{1}$, Wenti Dwi Marwita ${ }^{2}$ \\ widinopiardo@iainbatusangkar.ac.id ${ }^{1}$, wentydwimarwita@gmail.com²
}

\begin{abstract}
The problem in this research is that not all components of the accounting report made by the officer, such as the report on changes in assets, are not yet available. The recording process still has a very simple report format according to the knowledge of the registrar. Reports on changes in funds are only recorded for the amount of money in and out without any other supporting information. The audit of zakat accounting reports is only carried out internally. From the initial data, the researchers are interested in discussing it. The method in this study uses a descriptive approach that aims to explain the solution to existing problems based on data to be analyzed and interpreted. The results showed that the application of Zakat Accounting based on PSAK 109 in LAZIS MU Payakumbuh City as follows: Initial Recognition of Zakat, the receipt of zakat is recognized when cash or other assets are received. Measurement After Initial Recognition, if there is a decrease in the value of non-cash zakat assets, the amount of loss incurred must be treated as a deduction of zakat funds or as a deduction for amil funds. Initial recognition of infaq / alms, infaq / alms received is recognized as bound or unrestricted infaq / alms funds in accordance with the objective of the donors of infaq / alms in the amount received. Measurement after initial recognition, donations / alms received can be in the form of cash or non-cash assets. Non-cash assets can be in the form of current or non-current assets. The distribution of infaq / alms, the distribution of infaq / alms funds is recognized as a deduction for infaq / alms funds in the amount given. Non-halal Funds, Non-halal receipts are all receipts from activities that are not in accordance with sharia principles, including receiving current accounts or interest from conventional banks. Presentation, Amil presents zakat funds, infaq / alms funds, amil funds, and non-halal funds separately in the balance sheet of the financial position statement. Amil zakat discloses matters related to zakat transactions. Transitional provisions, this statement applies to transactions of zakat and infaq / alms that occur on or after the effective date. Effective Date, the presentation of financial statements based on PSAK 109 began to apply LAZIS MU Payakumbuh City since 2015. Constraints so far in LAZIS MU Payakumbuh City are still limited human resources in applying PSAK 109. There is no PSAK 109 training program for managers who manage finances, so far it is still understand independently, so that the management's knowledge is limited. In addition, operational costs are also limited, so they have limitations in carrying out activities that are to improve the quality of human resources, especially in the financial sector.
\end{abstract}

Keywords: Zakat Accounting, PSAK 109

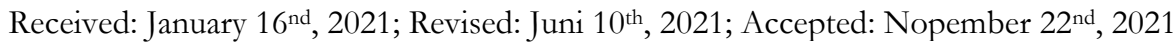

1,2 Institut Agama Islam Negeri Batusangkar and Jl. Jenderal Sudirman No.137, Limo Kaum, Lima Kaum, Kabupaten Tanah Datar, Sumatera Barat

E-mail: ${ }^{1}$ widinopiardo@,iainbatusangkar.ac.id , ${ }^{2}$ wentydwimarwita@gmail.com

DOI: https://doi.org/10.24952/tijaroh.v6i2.2453 


\section{Introduction}

In the Islamic economic system, zakat is one of the fiscal instruments to achieve the goals of socio-economic justice and the distribution of wealth and income. Thus, it means that zakat is identical with the Islamic moral philosophy. Zakat is also a reflection of the glory of Islam, zakat motivates the muzaki to always clean his property while helping his relatives in need.

The word zakat is the root word for zaka which means pure, growing, blessing, and praiseworthy. Zakat according to the term fiqh is a certain amount of property that must be submitted to people who are entitled according to the law of Allah. The word zakat in the terminology of the Koran is equivalent to the word shadaqah. Zakat has the main function of cleansing the wealth and soul of muzzaki. (Mursyidi, 2003: 75)

Now, there is a growing public awareness to give zakat to institutions. This is marked by the development of the National Amil Zakat Agency and the Amil Zakat Institution in Indonesia. However, awareness of zakat and zakat funds has not fully touched all levels of society (Thoriquddin, 2015: 33). For this reason, good zakat management is needed to create social welfare.

From an economic perspective, zakat is a push factor for improving the condition of society, especially economic improvement, because with the distribution of zakat there will be a growth in the welfare of society in a broader sense. Zakat is a source of finance based on the principle of justice and a combination of public interests and property interests. Therefore, it requires professionalism in its management. One of the professional elements is transparency and accountability of zakat funds. Financial reports are a form of accountability by the Zakat Management Organization (OPZ) in collecting and distributing zakat, infaq and alms. To achieve accountable and transparent financial reports, an accounting standard is needed, namely PSAK 109, which regulates the accounting for zakat and infaq / alms.

In Indonesia, the Zakat Management Organization (OPZ) is divided into two, namely the National Amil Zakat Agency (BAZNAS) and the Amil Zakat Institute (LAZ). BAZNAS is divided into three levels, namely: RI BAZNAS at the central level, Provincial BAZNAS at the Provincial Level, and Regency / City BAZNAS at the Regency / City level. While the Amil Zakat Institution (LAZ) is on a national scale, some are on a provincial scale, and some are on a district / city scale. 
One of the OPZs is the Muhammadiyah Institute for Zakat and Infak Alms (LAZISMU). LAZIZMU is a national scale LAZ that has opened branches in every Province in Indonesia to most districts / cities in Indonesia, including in Payakumbuh City. LAZISMU in the City of Payakumbuh was originally BPUZIS (the Management Body for Zakat Infak Shadaqah Muhammadiayah) which was founded on May 2, 1995. In 2002 BPUZIS changed its name to LAZIS MU inaugurated by the Muhammadiyah Regional Leaders of Payakumbuh City on April 20, 2011 as an extension of its arm. LAZIS MU Pusat which has achieved legality as a National Zakat Institution with the Decree of the Minister of Religion No. 457 of 2002. With the enactment of the Zakat Law number 23 of 2011, Government Regulation number 14 of 2014, and the Decree of the Minister of Religion of the Republic of Indonesia number 333 of 2015. LAZIS MU as a national amil zakat institution has been reaffirmed through the Decree of the Minister of Religion of the Republic of Indonesia number 730 of 2016.

LAZISMU Payakumbuh City has one coordinator from the Muhammadiyah Regional Leadership, seven administrators, and one Amil who work hand in hand in their service and Alhamdulillah more and more days are experiencing positive developments so that recruiting several Amil people to run executors who have been in charge of certain parts, namely the head representatives in the general, association, utilization, and administration and finance. Regarding transparency in the financial sector LAZISMU Payakumbuh has tried to implement its financial records based on PSAK 109.

LAZISMU Payakumbuh City in receiving and distributing zakat is required to make zakat accounting reports every year. To make the annual report required documents and records of transactions relating to the financial management of zakat. The Zakat Accounting Report is proof of the responsibility of the management in financial management at LAZISMU Payakumbuh City so that it can be known and guided by those with an interest in zakat finance. (Wida, Interview, 20 May 2020)

Based on a preliminary survey through an interview with one of the LAZISMU management in Payakumbuh, namely Mrs. Wida, information was obtained that: 1) the officer made not all components of the accounting report, such as the report on changes in assets. 2) financial recording still uses a very simple report format according to the knowledge of the registrar. 3) the report on changes in funds shall only record the amount of money in and out without any other supporting information. 4) the audit of zakat accounting reports is only carried out internally. (Wida, Interview, 20 May 2020) 
Researchers assume there are other conditions related to the application of PSAK 109 and the constraints of its application in LAZIZMU Payakumbuh City, therefore research is needed to in-depth. Based on the background of the problem above, the researcher is interested in raising the title of research on the Application of Zakat Accounting Based on PSAK 109 in LAZISMU Payakumbuh City.

\section{Literature Review}

Accounting for Zakat Based on PSAK 109 it is needed by institutions / bodies that have been approved by the government to collect, manage and then distribute it to Mustahiqs because in the collection, management and distribution of it, it is necessary to record and report so that those who issue zakat have more trust in zakat management institutions / agencies.

The objectives in zakat accounting according to Arif Mufraini:

1) Providing the necessary information to properly, efficiently and effectively manage zakat, infaq, alms, waqf and gifts entrusted to the body receiving zakat which aims to control management for the internal interests of the organization.

2) Providing information that is possible for zakat managers (management) to report on the implementation of responsibilities in properly and effectively managing the program and the use of all zakat under their authority, and possibly for zakat managers to report to the public the results of operations and use of public funds aiming at accountability (Mufraini, 2018: 11)

\section{PSAK No. 109}

OPZ financial reports can be a means of communication between OPZs, because ZIS financial reports are a form of operational responsibility for an OPZ, namely the activities of collecting and distributing zakat, infaq and alms (ZIS) funds. In order for financial reports to be transparent and accountable, there must be accounting standards governing this matter. The preparation of the financial statements of the amil ZIS institution refers to PSAK No. 109, and if there are things that are not regulated in PSAK 109 then the related PSAK can be used as long as it does not contradict the principles of Islamic sharia. The components of financial statements in PSAK 109 consist of statements of financial position (balance sheet), reports of changes in funds, reports of changes in assets under management, reports of cash flows and notes to financial statements. 
Widi Nopiardo, Wenti Dwi Marwita

Implementation of Zakat Accounting Based on PSAK 109 in Lazismu Payakumbuh City

\section{Accounting for Zakat and Infaq / Sadaqah Based on PSAK No. 109}

The current ZIS accounting standard used by OPZ as a guide in its financial accounting and reporting is PSAK No. 109 issued by the Indonesian Institute of Accountants (IAI) in 2010. The issuance of this PSAK has undergone a long process of approximately four years from the time of its preparation, starting with the preparation of its Exposure Draft (ED) which was issued in 2008. However, when Not all OPZs in Indonesia can apply PSAK No. 109. This was because some OPZs experienced several obstacles in their implementation. One of the constraining factors is the difficulty in human resources owned by OPZ.

Accounting for zakat in the Statement of Financial Accounting Standards (PSAK) No. 109 aims to regulate the recognition, measurement, presentation and disclosure of zakat and infak / alms transactions. This PSAK applies to amil, namely an organization / entity managing zakat whose formation and confirmation are regulated based on statutory regulations intended to collect and distribute zakat and infaq / alms, not for sharia entities that receive and distribute ZIS but not their main activities. For these entities, it refers to PSAK 101 concerning Presentation of Sharia Financial Statements. Amil who does not get a license can also apply PSAK No. 109. This PSAK refers to several MUI fatwas (Washilah and Nurhayati: 2013), namely:

a. MUI Fatwa no. 8/2011 concerning amil zakat,

b. MUI Fatwa No. 13/2011 concerning the Law of Zakat on Haram Assets,

c. MUI Fatwa No. 14/2011 on the Distribution of Zakat Assets in the form of Managed Assets.

d. MUI Fatwa No.15 / 2011 regarding the withdrawal, maintenance and distribution of zakat assets

\section{Recognition and Measurement (PSAK 109)}

\section{a. Accounting for Zakat}

1) Receipt of Zakat Based on PSAK 109 is recognized when cash or non-cash assets are received and 'recognized as an addition to zakat funds. If received in cash, it is recognized at the amount received, but if in non-cash form, it is the fair value of the asset. Determination of the fair value of non-cash assets 
received using market prices. If market prices are not available, other fair value determination methods in accordance with the relevant PSAK can be used.

2) If the muzakki determines the mustahik who must receive zakat distribution through amil, then the zakat assets received are all recognized as zakat funds and there is no share of amil on the zakat received and amil can receive ujrah for zakat distribution activities. If for this service amil gets a fee, it is recognized as an addition to amil funds.

3) Decrease in the value of Zakat assets. Based on PSAK 109 recognized as 1. A deduction of zakat funds, if this occurs it is not caused by amil's negligence; 2. Loss and deduction of amil funds, if caused by amil's negligence.

4) Zakat distributed to mustahik is recognized as a deduction from zakat funds with information according to the mustahik group including if it is distributed to Amil, in the amount of: 1. The amount given, if the gift is made in cash, in a journal, 2. The recorded amount, if the gift is made in the form of non-cash assets, journals:

5) Amil has the right to take part of the zakat to cover operational costs in carrying out his functions.

6) The burden of collecting and distributing zakat must be taken from the amil portion.

7) Zakat based on PSAK 109 is said to have been distributed to mustahik-nonamil only when it has been received by said mustahik-non-amil. If Zakat based on PSAK 109 is distributed through other amil, it is recognized as a receivable for distribution and for the amil who receives it is recognized as a distribution liability (debt). Receivables and liabilities decrease when Zakat based on PSAK 109 is distributed. Other amil have no right to take part of the zakat fund, but can get ujrah from the previous amil.

8) Zakat funds distributed in the form of acquisition of fixed assets (assets under management) are recognized as:

a) All zakat distribution, if the fixed assets are handed over to be managed by other parties who are not controlled by amil.

b) Gradual distribution is measured at the depreciation of the fixed assets according to their utilization pattern, if the fixed assets are still under amil's control or another party is controlled by amil. 
9) Amil must disclose the following matters related to zakat transactions, but not limited to:

a) Zakat distribution policies, such as determining the priority scale for zakat distribution and non-military mustahik;

b) b) Zakat distribution policies for amil and mustahiq nonamil, such as percentage of distribution, reasons, and consistency of policies;

c) The method of determining the fair value used to receive zakat in the form of non-cash assets.

\section{b. Accounting for Infaq / Alms}

1) Receipt of Infaq / Alms is recognized when cash or non-cash assets are received and recognized as an addition to bound or unbound infaq / alms funds in accordance with the purpose for which it was given. If received in cash, it is recognized at the amount received, but if in non-cash form, it is the fair value of the asset. Receipts for non-cash assets can be grouped into current assets and non-current assets. Current assets are assets that must be distributed immediately, and can be in the form of consumables such as foodstuffs; or items that have long-term benefits such as a car for an ambulance. Current non-cash assets are valued at cost.

2) Non-current assets received by amil and entrusted with management are valued at fair value at the time of receipt and are recognized as non-current assets in donations / alms. Depreciation of these assets is treated as a deduction from the bound infaq / alms funds if the use or management of the assets has been determined by the donor.

3) Impairment of infaq / sadaqah assets is recognized as:

a) deduction of infaq / alms funds, if it occurs is not caused by amil's negligence.

b) Loss and deduction of amil funds, if caused by amil's negligence.

4) Infaq / alms funds before distribution can be managed for a temporary period to obtain optimal results. Proceeds from management funds are recognized as an addition to infaq / alms funds. 
5) The distribution of infaq / alms funds is recognized as a deduction for infaq / alms funds in the amount of:

a) The amount submitted, if in cash.

b) The carrying value of the assets given up, if in the form of non-cash assets.

6) The distribution of infaq / alms by amil to other amil is a distribution that reduces infaq / alms funds as long as amil will not receive back the donated / alms assets that have been distributed.

7) The distribution of infaq / alms to the final recipient in the revolving fund scheme is recorded as revolving infaq / alms receivables and does not reduce infaq / alms funds.

8) Amil must disclose the following matters in relation to infak / alms transactions, but not limited to:

a) Infaq / alms distribution policies, such as determining the priority scale for distribution and recipients;

b) Distribution policy between amil funds and nonamil funds for receiving infaq / alms such as percentage of distribution, reasons and consistency of policies

c) The method of determining the fair value used to receive infaq / alms is in the form of non-cash assets;

d) The existence of infaq / sadaqah funds that are not directly distributed but managed first, if any, then the amount and percentage of all infaq / alms receipts must be disclosed during the reporting period and the reasons for this.

e) The results obtained from the management referred to in number (4) are disclosed separately

f) The use of infaq / alms funds becomes a managed asset designated for those who have the right, if any, the amount and percentage of all infak / alms fund usage and the reasons thereof;

g) Details of infaq / alms funds based on their allocation, bound and not bound

h) The relationship between amil and the recipient of infaq / alms including: the nature of the special relationship; Amount and type of assets 
Widi Nopiardo, Wenti Dwi Marwita

Implementation of Zakat Accounting Based on PSAK 109 in Lazismu Payakumbuh City

distributed; and The percentage of assets channeled from the total distribution during the period

i) The existence of non-halal funds, if any, is disclosed regarding the policies for receiving and channeling funds, the reasons and the amount; and

j) Amil's performance on the receipt and distribution of zakat funds and infaq / alms funds.

\section{c. Nonhalal Fund}

1) Non-halal receipts are all receipts from activities that are not in accordance with sharia principles, including but not limited to giro or interest received from conventional banks. Non-halal acceptance generally occurs in emergencies or conditions that are not desired by sharia entities because they are prohibited in principle.

2) Non-halal receipts are recognized as non-halal funds, which are separate from zakat funds, infaq / alms funds and amil funds. Non-halal assets are channeled in accordance with sharia.

\section{d. Amil Zakat, Infaq and Alms Financial Statements}

Financial statements can be said to be the end result of an accounting process. The main objective of financial reports is to provide relevant information to interested parties, both internal and external, such as muzakki, government, other parties who provide resources to OPZ and also the public. These parties have different interests from the information in a financial report relating to making a decision. The financial report is also a form of accountability report from management / manager for resource management activities that have been mandated to it. In general, a financial report provides information about (Kurniasari, 2011: 97)

1) The number and nature of the assets, liabilities and net assets of an organization,

2) The effects of transactions, other events and situations that change the value and nature of net assets, 
3) The types and amounts of cash inflows and cash outflows from resources in a period and the relationship between them,

4) how an organization gets and spends cash, obtains loans and repays loans, other factors that affect its liquidity,

5) The service business of an organization.

The form of financial statements for amil or OPZ is based on PSAK No. 109 of them are as follows:

1) Balance Sheet (statement of financial position);

2) Fund Change Report

3) Report on Changes in Assets Under Management

4) Cash flow statement

5) Notes to financial statements

\section{Methods}

This type of research is a qualitative descriptive study, where basically this type of research emphasizes the inductive process and on the analysis of the dynamics between the observed phenomena, using scientific logic. (Saifuddin Azwar, 2004: 65)

In this study, researchers describe the application of zakat accounting based on PSAK 109 in LAZISMU Payakumbuh City and the constraints in the application of zakat accounting based on PSAK 109 in LAZIS MU Payakumbuh City. The research that the researchers conducted was located at LAZISMU Payakumbuh City, the research will be carried out from January to July 2020. In conducting this research, the researcher immediately became a key instrument by directing the researcher to the field to research, namely by using a list of questions and interviews related to making Zakat accounting reports based on PSAK 109 in LAZIS MUKota Payakumbuh.

The primary data sources in this study were obtained from the chairman, namely Mr. H. Amri Alza, S.IP, the secretary, namely Mr. Zikriman Zainal, SH, and the treasurer of LAZISMU Payakumbuh, Mr. H. Akmal Syukri. Meanwhile, secondary data sources are documents in the form of financial transaction records, receipts, and other necessary supporting documents.

In this study, researchers used interview and documentation techniques. After all the data has been collected, the next step is to perform data analysis, the data analysis 
Widi Nopiardo, Wenti Dwi Marwita

Implementation of Zakat Accounting Based on PSAK 109 in Lazismu Payakumbuh City

technique used in this research is qualitative methods. Data analysis techniques have the principle of processing data and analyzing the collected data into systematic, orderly, structured, and meaningful data. Miles and Huberman in Sugiyono (2014: 246-253) suggest that activities in qualitative data analysis are carried out interactively and continue to completion, so that the data is saturated. Activities in data analysis, namely: the data reduction stage, the data presentation stage, and the conclusion (verification) stage.

In this study to obtain data validity, researchers used triangulation techniques. Triangulation is a data validity checking technique that utilizes something other than the data for the purpose of checking or comparing the data. (Lexy J. Moleong 2009: 330)

\section{Result and Discussion}

Based on the research that has been done, the following results are obtained:

\section{Application of Zakat Accounting Based on PSAK 109 in LAZISMU Payakumbuh City.}

Initial recognition of zakat at LAZISMU Payakumbuh City, the receipt of zakat is recognized when cash or other assets are received. Zakat received from muzakki is recognized as an addition to zakat funds. Determination of the fair value of non-cash assets received using market prices. If market prices are not available, then other fair value determination methods may be used in accordance with the relevant PSAK. Zakat received is recognized as amil funds for the amil portion and zakat funds for the non-military portion. Determination of the amount or percentage of parts for each mustahiq is determined by amil in accordance with sharia principles and amil's policy. If the muzakki determines the mustahiq who must receive zakat distribution through amil, the zakat assets received are fully recognized as zakat funds. If for this service amil gets a fee, it is recognized as an addition to amil funds.

Measurement After Initial Recognition, if there is a decrease in the value of non-cash zakat assets, the amount of the loss incurred must be treated as a deduction of zakat funds or amil funds depending on the cause of the loss. A decrease in the value of zakat assets is recognized as a deduction from zakat funds, if it occurs not due to amil's negligence. Zakat distribution, Zakat distributed to mustahiq is recognized as a deduction from zakat funds in the amount given. Initial recognition of infaq / alms, infaq / sadaqah received is recognized as bound or unrestricted infaq / alms funds in accordance with the purpose of the donors / alms at the amount received, if in cash, 
Determination of the fair value of non-cash assets received using the market price for the assets the nonkas. If market prices are not available, then other fair value determination methods may be used in accordance with the relevant PSAK. Infaq / sadaqah received is recognized as amil funds for the amil portion and infaq / alms funds for the portion of infaq / alms recipients. Amil is determined by the amil in accordance with sharia principles and amil's policies.

Measurement after initial recognition, donations / alms received can be in the form of cash or non-cash assets. Non-cash assets can be in the form of current or non-current assets. Non-current assets received by amil and entrusted with management are valued at fair value at the time of receipt and are recognized as noncurrent assets in donations / alms. Depreciation of these assets is treated as a deduction from bound infaq / alms funds if the use or management of the assets has been determined by the donor. Amil can also receive non-cash assets which are intended by the giver to be distributed immediately. Such assets are recognized as current assets. These assets can be in the form of consumables, such as foodstuffs; or assets with a long economic life, such as an ambulance. Current non-cash assets are valued at cost, while non-current assets are valued at fair value in accordance with the relevant PSAK. In the event that amil receives donations / alms in the form of noncurrent assets (non-cash) managed by amil, the assets must be valued in accordance with the relevant PSAK. Infaq / alms funds before being distributed can be managed for a temporary period to get optimal results. Proceeds from management funds are recognized as an addition to infaq / alms funds.

Distribution of infaq / alms, the distribution of infaq / alms funds is recognized as a deduction for infaq / alms funds in the amount given. The distribution of infaq / alms to other amil is a distribution that reduces infaq / alms funds as long as the amil will not receive back the donated / alms assets that have been distributed. The distribution of infaq / alms to the final recipient in the revolving fund scheme is recorded

as revolving infaq / alms receivables and does not reduce infaq / alms funds. Non-halal Funds, Non-halal receipts are all receipts from activities that are not in accordance with sharia principles, including, among others, receipts from current accounts or interest from conventional banks. Non-halal acceptance generally occurs in emergencies or conditions that are not desired by sharia entities because they are 
Widi Nopiardo, Wenti Dwi Marwita

Implementation of Zakat Accounting Based on PSAK 109 in Lazismu Payakumbuh City

prohibited in principle. Non-halal receipts are recognized as non-halal funds, which are separate from zakat funds, infaq / alms funds and amil funds.

Presentation, Amil presents zakat funds, infaq / alms funds, amil funds, and non-halal funds separately in the balance sheet of the financial position statement. Disclosure, Amil revealed the following matters related to zakat transactions, Amil also revealed the following matters related to infaq / alms transactions. In addition to making disclosures of Zakat, infaq / sadaqah, amil discloses matters regarding the existence of non-halal funds, if any, is disclosed regarding policies for the receipt and distribution of funds, reasons, and amounts; and amil's performance on the receipt and distribution of zakat funds and infaq / alms funds. Transitional provisions, this statement applies to transactions of zakat and infaq / alms that occur on or after the effective date. Effective Date, the presentation of financial statements based on PSAK 109 came into effect LAZIS MU Payakumbuh City since 2015

Thus it can be argued that the principles contained in PSAK 109 have mostly been applied to LAZISMU Payakumbuh City, the format of the annual report has also followed PSAK 109. It needs administrative arrangements so that it is more comprehensive to support the application of this PSAK 109, connected manual records. The IT system must be maximized so that the required data related to finance can be presented quickly and accurately to support institutional accountability.

2. Constraints in the Application of Zakat Accounting Based on PSAK 109 in LAZISMU Payakumbuh City

Limited human resources in the field of accounting, obstacles so far in LAZIS MU Payakumbuh are still limited human resources in understanding PSAK 109. There is no PSAK 109 training program for managers who manage finances, so far they only understand independently, so that the management's knowledge is limited. Operational costs are limited, so they have limitations in carrying out activities that are to improve the quality of human resources, especially in the financial sector.

\section{Conclusion}

Application of Zakat Accounting Based on PSAK 109 in LAZIS MU Payakumbuh City. Initial recognition of zakat, receipt of zakat is recognized when cash or other assets are received. Measurement after initial recognition, if there is a decrease in the value of non-cash zakat assets, the amount of the loss incurred must be treated as a deduction for 
zakat funds or a deduction from the amil funds for zakat distribution, zakat distributed to mustahiq is recognized as a deduction for zakat funds in the amount given. Initial recognition of infaq / alms, infaq / alms received is recognized as bound or unrestricted infaq / alms funds in accordance with the purpose of the donors of infaq / alms in the amount received. After initial recognition, the infaq / alms received can be in the form of cash or non-cash assets. Non-cash assets can be in the form of current or non-current assets. Distribution of infaq / alms, the distribution of infaq / alms funds is recognized as a deduction for infaq / alms funds in the amount given. Non-halal Funds, Non-halal receipts are all receipts from activities that are not in accordance with sharia principles, including, among others, receipts from current accounts or interest from conventional banks. Presentation, Amil presents zakat funds, infaq / alms funds, amil funds, and non-halal funds separately in the balance sheet of the financial position statement. Amil zakat discloses matters related to zakat transactions. Transitional provisions, this statement applies to transactions of zakat and infaq / alms that occur on or after the effective date. Effective date, presentation of financial statements based on PSAK 109 came into effect LAZIS MU Payakumbuh City since 2015. The constraints so far in LAZIS MU Payakumbuh are still limited human resources in understanding PSAK 109. There is no PSAK 109 training program for managers who manage finances, so far they still understand independently, so the management's knowledge is limited. Operational costs are limited, so they have limitations in carrying out activities that are to improve the quality of human resources, especially in the financial sector.

\section{References}

Kurniasari, Wiwin. Transparansi Pengelolaan Masjid dengan Laporan Kenangan Berdasarkan Pernyataan Standar Akuntansi Keuangan (PSAK 45).Jurnal Muqtashid. Vol.2, No.1 Juni 2011: STAIN Salatiga

Lexy J. Moleong 2009, Metodologi Penelitian Kualitatif, Bandung: Remaja Rosdakarya,

Mufraini, Arief. 2018, Akuntasi dan Manajemen Zakat: Mengomunikasikan Kesadaran dan Membangun Jaringan. Jakarta: Kencana Prenada Media Group.

Mursyidi, 2003, Akuntansi Zakat Kontemporer, PT.Remaja Rosdakarya Offset, Bandung

Nurhayati, Sri dan Wasilah. 2013. Akuntansi Syariah di Indonesia. Jakarta: Salemba Empat 
Widi Nopiardo, Wenti Dwi Marwita

Implementation of Zakat Accounting Based on PSAK 109 in Lazismu Payakumbuh City

Saifuddin Azwar, Metode Penelitian, Yogyakarta: Pustaka Pelajar, Cet-5, 2004

Sartika Wati HS Arief 2017, Analisis Penerapan PSAK No. 109 Tentang Akuntansi Zakat, Infaq/Sedekah Pada Badan Amil Zakat Nasional Kota Manado

Sugiyono. 2013. Metode Penelitian Pendidikan Pendekatan Kuantitatif, Kualitatif, dan RひD. Bandung: Alfabeta

----------. 2014. Metode Penelitian Pendidikan Pendekatan Kuantitatif, Kualitatif, dan R®D. Bandung: Alfabeta

Thoriquddin, M. 2015. Pengelolaan Zakat Produktif Perspektif Maqasid Al-Syari'ah Ibnu 'Asyur. Malang: UIN Maliki Press.

Undang-Undang No. 23 Tahun 2011 Tentang Pengelolaan Zakat

Wida, Wawancara, 20 Mei 2020 